\title{
[Erratum]
}

\section{Study of developmental disorders among newborns in Fukushima City after the Great East Japan Earthquake and nuclear power plant accident ; an adjunct study of the Fukushima Regional Center of the Japan Environmental and Children's Study (JECS)}

\author{
Shuntaro Itagaki, Tomohiro Wada, Shunya Yokokura, Yoko Ise, Akiko Sato, \\ Takatomo Matsumoto, Hirobumi Mashiko, Shin-ichi Niwa and Hirooki Yabe \\ Department of Neuropsychiatry, School of Medicine, Fukushima Medical University
}

\section{FUKUSHIMA JOURNAL OF MEDICAL SCIENCE Vol. 65 (2019) No. 1, 1-5}

This is based on a survey of two-year-old but not three-year-old cohorts. Therefore, we cannot state anything about the incidence of autism spectrum disorder (ASD) in over three-years-old children. We submit corrections in the following errata, because the original sentences might mislead the readers without evidence from three-year-old children. Also, we would like to exclude the phrase of "low-dose radiation" from the sections of Key word, Abstract, and Conclusion, because this study did not cover its influence.

Author Shuntaro Itagaki

August 05, 2019

\begin{tabular}{|c|c|c|}
\hline Correction point & Before correction & After correction \\
\hline Abstract p 1 line 1-3 & $\begin{array}{l}\text { The present adjunct study of the Ja- } \\
\text { pan Environment and Children's } \\
\text { Study (JECS) aimed to determine the } \\
\text { occurrence of developmental disor- } \\
\text { ders in Fukushima Prefecture, which } \\
\text { was exposed to low-dose radiation. }\end{array}$ & $\begin{array}{l}\text { The present adjunct study of the Ja- } \\
\text { pan Environment and Children's } \\
\text { Study (JECS) aimed to determine the } \\
\text { occurrence of developmental disor- } \\
\text { ders in Fukushima Prefecture. }\end{array}$ \\
\hline Abstract p 1 line 13-14 & $\begin{array}{l}\text { Autism spectrum disorder (ASD) is } \\
\text { not obvious by the age of three years } \\
\text { and thus it might become apparent as } \\
\text { the children grow older. }\end{array}$ & $\begin{array}{l}\text { A follow-up survey should be imple- } \\
\text { mented, because this study focused } \\
\text { only on children aged two years. }\end{array}$ \\
\hline Key words & $\begin{array}{l}\text { neonate, developmental disorder, pe- } \\
\text { diatric health, disaster, low-dose radi- } \\
\text { ation }\end{array}$ & $\begin{array}{l}\text { neonate, developmental disorder, pe- } \\
\text { diatric health, disaster }\end{array}$ \\
\hline Discussion p 4 line 29 & ASD & Autism spectrum disorder (ASD) \\
\hline Discussion $\mathrm{p} 4$ line $51-53$ & $\begin{array}{l}\text { The present survey targeted only } \\
\text { children aged } 24 \text { months, and thus } \\
\text { ASD might become apparent in future } \\
\text { surveys. }\end{array}$ & $\begin{array}{l}\text { The present survey targeted only } \\
\text { children aged } 24 \text { months, and thus a } \\
\text { follow-up survey should be imple- } \\
\text { mented. }\end{array}$ \\
\hline Conclusion $\mathrm{p} 4$ line $76-79$ & $\begin{array}{l}\text { We found no evidence of an increase } \\
\text { in the incidence of developmental dis- } \\
\text { orders among two-year-old infants } \\
\text { born in Fukushima City after it was } \\
\text { exposed to low-dose radiation. }\end{array}$ & $\begin{array}{l}\text { We found no evidence of an increase } \\
\text { in the incidence of developmental dis- } \\
\text { orders among two-year-old infants } \\
\text { born in Fukushima City. }\end{array}$ \\
\hline
\end{tabular}


Conclusion p 4 line 82-85 Because symptoms of developmental disorders in the children might emerge as they grow older, a followup survey should be implemented.
Since this study focused only on children aged two years, further followup studies are needed to confirm and extend these results. 